$12 / 8,98595(1)$

\title{
Bibliography of Greenhouse-Gas Reduction Strategies
}

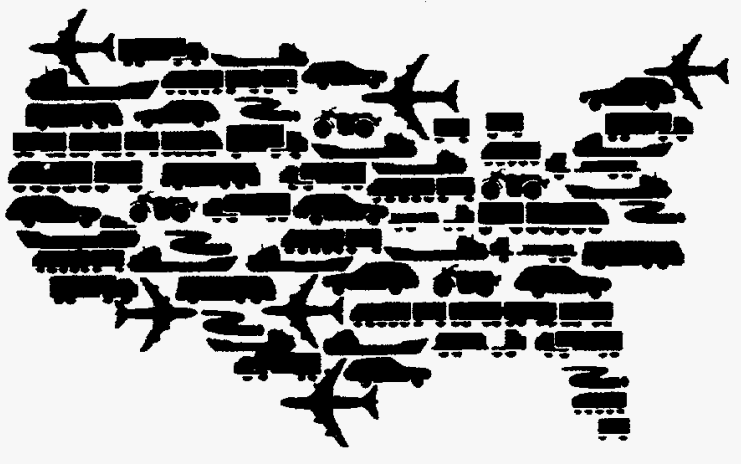

Center for Transportation Research Argonne National Laboratory

Operated by The University of Chicago, under Contract W-31-109-Eng-38, for the 


\section{Argonne National Laboratory}

Argonne National Laboratory, with facilities in the states of Illinois and Idaho, is owned by the United States Government, and operated by the University of Chicago under the provisions of a contract with the Department of Energy.

This technical memo is a product of Argonne's Energy Systems (ES) Division. For information on the division's scientific and engineering activities, contact:

Director, Energy Systems Division

Argonne National Laboratory

Argonne, llinois 60439-4815

Telephone (708) 252-3724

Presented in this technical memo are preliminary results of ongoing work or work that is more limited in scope and depth than that described in formal reports issued by the ES Division.

Publishing support services were provided by Argonne's Information and Publishing Division.

\section{Disclaimer}

This report was prepared as an account of work sponsored by an agency of the United States Government. Neither the United States Government nor any agency thereof, nor any of their employees, makes any warranty, express or implied, or assumes any legal liability or responsibility for the accuracy, completeness, or usefulness of any information, apparatus, product, or process disclosed, or represents that its use would not infringe privately owned rights. Reference herein to any specific commercial product, process, or service by trade name, trademark, manufacturer, or otherwise, does not necessarily constitute or imply its endorsement, recommendation, or favoring by the United States Government or any agency thereof. The views and opinions of authors expressed herein do not necessarily state or reflect those of the United States Government or any agency thereof. 


\section{DISCLAIMER}

Portions of this document may be illegible in electronic image products. Images are produced from the best available original document. 


\section{Bibliography of Greenhouse-Gas Reduction Strategies}

\section{M.M. Tompkins* and M.M. Mintz}

Center for Transportation Research, Energy Systems Division, Argonne National Laboratory, 9700 South Cass Avenue, Argonne, Illinois 60439

March 1995

Work sponsored by United States Department of Energy, Office of Policy, Planning, and Program Evaluation

DISTRIBUTION OF THIS DOCUMENT IS UNLIMITED

"Tompkins is affiliated with Argonne's Decision and Information Sciences Division. 


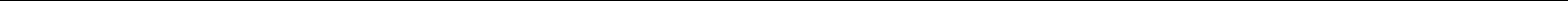




\section{Contents}

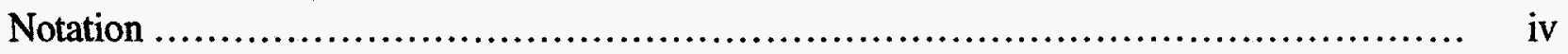

Abstract....................................................................... 1

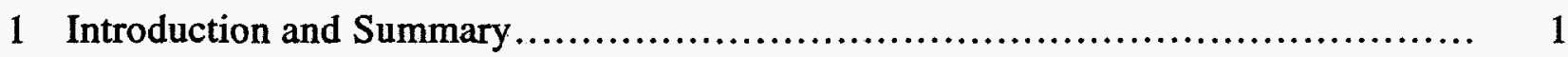

1.1 Literature Review ....................................................... 1

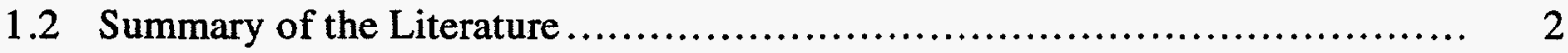

2 Annotated Bibliography ..................................................... 5

3 Documents and Related Reference Materials ................................... 37 


\section{Notation}

$\begin{array}{ll}\text { AVO } & \text { average vehicle occupancy } \\ \text { CAA } & \text { Clean Air Act } \\ \text { CAFE } & \text { corporate average fuel economy } \\ \text { chlorofluorocarbons } \\ \text { CFC } & \text { compressed natural gas } \\ \text { CNG } & \text { U.S. Department of Energy } \\ \text { DOE } & \text { U.S. Department of Transportation } \\ \text { DOT } & \text { U.S. Environmental Protection Agency } \\ \text { EPA } & \text { greenhouse gas } \\ \text { GHG } & \text { gross national product } \\ \text { GNP } & \text { hydrocarbon } \\ \text { HC } & \text { high-occupancy vehicle } \\ \text { HOV } & \text { indirect-source regulations } \\ \text { ISR } & \text { Intermodal Surface Transportation Efficiency Act } \\ \text { ISTEA } & \text { intelligent vehicle highway system } \\ \text { IVHS } & \text { low-emission vehicle } \\ \text { LEV } & \text { liquefied petroleum gas (propane) } \\ \text { LPG } & \text { Mobile Emissions Reduction Crediting } \\ \text { MERC } & \text { miles per gallon } \\ \text { MPG } & \text { original equipment manufacturer } \\ \text { OEM } & \text { Office of Technology Assessment } \\ \text { OTA } & \text { research and development } \\ \text { R\&D } & \text { single-occupant vehicle } \\ \text { SOV } & \text { transportation control measure } \\ \text { TCM } & \text { transportation demand management } \\ \text { TDM } & \text { vehicle miles traveled } \\ \text { VMT } & \text { volatile organic compound } \\ \text { VOC } & \text { zero-emission vehicle } \\ \text { ZEV } & \end{array}$




\title{
Bibliography of \\ Greenhouse-Gas Reduction Strategies
}

by

M.M. Tompkins and M.M. Mintz

\begin{abstract}
A bibliography of greenhouse-gas reduction strategies has been compiled to assist the Climate Change Action Plan Task Force in their consideration of strategies to reduce greenhouse-gas emissions from personal motor vehicles. The document contains a summary of the literature, including its major directions and implications; an annotated listing of 32 recent pertinent documents; and a listing of a larger group of related reports.
\end{abstract}

\section{Introduction and Summary}

This document is one of a series of informational materials intended to assist members of the Climate Change Action Plan Task Force in their consideration of strategies to reduce greenhouse-gas (GHG) emissions from personal motor vehicles. It is divided into three sections: (1) a brief summary of the literature, its major directions and implications; (2) an annotated bibliography of 32 recent documents that are considered the most pertinent to the subject; and (3) a broader list of references that includes not only those 32 documents but also a larger group of related reports.

\subsection{Literature Review}

Documents addressing the effects and effectiveness of policy instruments for reducing GHG emissions from personal motor vehicles cover a wide range of subjects. Since GHG emissions are inextricably bound to the combustion of carbon-based fuels, documents that address strategies to reduce passenger-miles traveled, improve vehicular energy efficiency, or reduce the carbon content of the fuels used are clear candidates for the literature review. Most of these strategies fall within the two broad categories of technology or policy initiatives. Within those categories, a host of specific technologies and policy options are potential candidates. Some of these options appear frequently in the literature on congestion relief or travel-demand reduction; others appear in the energy-demand literature; still others appear in the air-quality literature. Many are not typically considered GHG reduction strategies. However, since all strategies that reduce fossil energy use per passenger-mile traveled will also reduce GHG emissions, reports that discuss such strategies are legitimate candidates for this review. 
Prior to selection of the 32 documents to be summarized, most of the documents listed in Section 3 were screened. The screening process enabled us to limit the annotated bibliography to work published in the past two years. (The few pre-1992 entries included are considered particularly noteworthy.) We have also attempted to limit annotation to the most recent work by a single author or group of authors and to exclude documents that are extremely narrow in technical content.

\subsection{Summary of the Literature}

In addition to the individual summaries provided in the annotated bibliography, the literature can also be summarized by technical content, author affiliation, and regional support. Review of the literature in terms of these factors provides a different perspective from review of each document by itself - in effect, an answer to the question, "Who is considering which strategies in what locations?"

Technical content. On the basis of the sheer number of recent publications, two subject areas appear to be generating particularly strong interest: (1) research into market mechanisms to reduce vehicle-miles traveled (VMT) or improve fuel economy and (2) studies of the technical or regulatory feasibility of achieving higher levels of fuel efficiency. Over two-thirds of the documents in the annotated bibliography* (22 out of 32 ) consider some type of market mechanism to reduce VMT and/or improve fuel economy. Congestion pricing, the imposition of market-level fees for currently "free" parking, and feebates or other incentives to encourage the purchase of fuel-efficient vehicles are the most widely studied measures. Another 10 of the annotated documents consider increasing fuel economy via either technological improvements or corporate average fuel economy (CAFE) standards. Six documents deal with fuel substitution (i.e., the potential of alternative fuels to reduce GHG emissions). Another 10 documents cover growth management through improved land use and zoning, behavioral issues that reduce the effectiveness of VMT-reduction measures, and such nonmarket VMT-reduction measures as high-occupancyvehicle (HOV) lanes and other types of transportation control measures (TCMs).

Author affiliation. The bulk of the documents in both the annotated bibliography and the longer list of references have been published by federal agencies or environmental groups. Researchers from environmental organizations (e.g., the American Council for an Energy Efficient Economy, the Environmental Defense Fund, the World Wildlife Fund, the Union of Concerned Scientists, and the World Resources Institute) have been particularly prolific, publishing many more documents than have university-based researchers. While it is not immediately clear why, a combination of funding, research priorities, and internal policies may be involved. Research funds (and publishing budgets) may be more strained at universities, and most specifically at those institutions with a history of research in this field, than at environmental organizations. Environmental organizations may be capturing more external support and/or allocating more of

\footnotetext{
* Because an individual document may consider several strategies, the numbers cited sum to more than the number of documents reviewed.
} 
their internal funds to such research. Environmental organizations also may be adopting internal policies that encourage researchers to publish more of their work.

Certain distinctions between the publications of federal agencies and those of environmental groups emerge on the basis of the literature review. It appears that much research by environmental groups (environmentally affiliated research) tends to be relatively narrow in focus, examining only a handful of measures in a single concise, typically nontechnical, document. By contrast, most government-sponsored research is broader, examining many measures under a number of alternative scenarios; as a result, government-sponsored reports tend to be detailed, comprehensive, and geared to a more technical audience. This distinction suggests that environmentally affiliated research may have a somewhat broader appeal and a greater impact on the continuing policy debate. Environmentally affiliated researchers also tend to be more willing to commit to a conclusive policy stand, which is perhaps a reflection of their membership in a stakeholder group, as compared to government-sponsored researchers, who are often noncommital and intentionally equivocal in their conclusions.

The private sector is notably absent from the debate, which raises several interesting questions. Should the private sector have a separate voice in the technical debate, or is it already represented in the even-handedness typical of government research? What are the perceived risks preventing the private sector from playing a greater role? If public image is the major barrier, it is not clear that the private sector can afford to take on a more active role. On the other hand, if competition is the major barrier, consortia could provide an appropriate vehicle. However, unless all original equipment manufacturers are represented in the consortia, competitive risk could still be a problem.

Regional support. Conversations with some of the authors provide additional perspective on why these particular measures are evoking such interest and why much of the research activity is emanating from the West Coast. Unlike other regions of the country, California's South Coast Air Basin now has nearly seven years of experience with employee-trip reduction, as mandated by Regulation XV of the South Coast Air Quality Management District. ${ }^{1}$ California's Air Resources Board also has over 20 years experience in developing emission standards. At the same time, a number of local jurisdictions have accumulated up to 10 years of experience with transportation demand management (TDM), a broad class of strategies intended to increase the person-carrying capacity of existing transportation systems. Much of the accumulated experience with emission standards has been relatively positive, which may be why California has embarked on an ambitious program to mandate the sale of low-emission vehicles (LEVs). By contrast, experience with TDM, especially with employee-trip reduction, has been disappointing. Thus, it is not surprising that California-based researchers are in the vanguard of those experimenting with innovative VMT-reduction measures. Projects in various stages of development include congestion-pricing demonstrations on the San Francisco-Oakland Bay

1 As mandated by Regulation XV, employers with 100 or more employees must increase the average vehicle occupancy of their employees' worktrips by $25 \%$. A similar mandate contained in the 1990 Clean Air Act Amendments is in the process of being implemented in metropolitan areas with the most severe air-quality problems. 
Bridge, State Route 91, and Interstate 15 (I-15); innovative toll roads that require private management to maintain a minimum average vehicle occupancy; and peak-hour HOV buy-ins ${ }^{2}$ on I-15. California has also enacted legislation requiring that employers provide an optional cash benefit in lieu of parking (a parking "cash-out") if they provide subsidized parking to their employees.

While policy experimentation is not unique to California, that state does appear to be doing more than its fair share, much of it in response to environmental imperatives. Quite possibly, California has achieved a greater degree of consensus, defined here as a shared public perception of the problem, than most other regions. Most Californians understand that air quality is unacceptable in large areas of the state for much of the year and that major improvements are needed. If one accepts this view, then strong measures to reduce growth in VMT, to adopt and strictly enforce emission standards, and to require LEVs make sense. Pockets of similar consensus may be developing in Denver, Phoenix, and other cities in the Southwest.

The Pacific Northwest also appears to have achieved consensus, but, with less of an airquality problem, the imperative is quite different. In both Portland and Seattle, the public perceives urban sprawl as destructive to their lifestyle, and major initiatives have been launched (through The 1000 Friends of Oregon and The 1000 Friends of Washington) to manage growth and preserve open space. Minnesota also shows signs of moving in this direction.

In other regions, the populace does not appear to agree on the nature of the problem, let alone potential solutions. In portions of the Northeast, congestion and air quality are perceived as major problems, but the region as a whole has not yet achieved consensus on whether problems are severe enough to warrant strong actions. ${ }^{3}$ In most of the rest of the country, air quality is perceived as a minor problem and congestion is considered bothersome, but neither poor air quality nor traffic congestion has reached the level of broad public perception needed to support major initiatives.

2 HOV lanes in which use by a vehicle with fewer occupants is permitted upon payment of a higher fee.

3 The Ozone Transport Commission has approved adoption of the California LEV program in the Northeast, although individual states are not required to adopt the zero-emission-vehicle (ZEV) component of this program. 


\section{Annotated Bibliography}

Brinner, R., et al., An Analysis of Public Policy Measures to Reduce Carbon Dioxide Emissions from the U.S. Transportation Sector, DRI/McGraw-Hill for U.S. Environmental Protection Agency (EPA), Lexington, Mass., January 1991, 53 pages plus appendices.

Mechanisms:

Reduce travel demand

Improve fuel efficiency

Policy Instruments:

Economic incentives (fuel taxes, gas-guzzler taxes/gas-sipper rebates, oil import fee)

Summary:

This report focuses on three policy options to stabilize or reduce $\mathrm{CO}_{2}$ emissions from light-duty vehicles: gasoline taxes, gas-guzzler taxes/gas-sipper rebates, and an oil import fee. Detailed econometric models were used to estimate transportation sector impacts, such as VMT, fuel consumption, and miles per gallon (MPG). A macroeconomic model was used to estimate aggregate effects on the U.S. economy (changes in gross national product [GNP], imports, and investment) under three fiscal policy scenarios, one revenue-raising scenario, and two revenue-neutral scenarios. The three policy options are evaluated for two emissions scenarios: (1) achieving the goal of stabilizing $\mathrm{CO}_{2}$ emissions at their 1989 level for the next 20 years and (2) reducing $\mathrm{CO}_{2}$ emissions by $20 \%$ of their 1989 level by the year 2000 and maintaining that level through the year 2010 .

The study concludes that gas taxes are the preferred policy instrument since they affect both usage and efficiency. Gas taxes reduce $\mathrm{CO}_{2}$ emissions in four ways: accelerated scrappage of older vehicles, reduced VMT, increased fuel efficiency, and increased vehicle efficiency through better maintenance. The report demonstrates that gas taxes must rise dramatically to achieve the $20 \%$ reduction goal ( $\$ 4.75 /$ gal in 2010 ) but only moderately to stabilize emissions (\$1.55/gal in 2010).

Gas-guzzler taxes/gas-sipper rebates are not as economically efficient as gasoline taxes in achieving $\mathrm{CO}_{2}$ emissions reduction goals for two reasons: the "rebound" effect (the increase in VMT as a result of increased fuel efficiency), and the slowdown in fleet turnover. Achieving a given $\mathrm{CO}_{2}$ emissions reduction via a guzzler/sipper policy alone will be extremely difficult, since the policy must offset these two countervailing effects.

The analysis compares the effect of gradually increasing oil import fees to a maximum of $\$ 10$ per barrel with the gasoline tax option. Oil import fees were found to have a greater inflationary impact on the domestic economy than gasoline taxes due to the increased price of all energy-intensive goods. Through the year 2000 , increased real gasoline prices result in lower fuel consumption and, thereby, lower $\mathrm{CO}_{2}$ emissions. After 2000 , however, fuel prices stabilize and consumption increases, leading to $\mathrm{CO}_{2}$ emissions within $2 \%$ of the baseline.

In all cases, the analysis indicates that the greater the $\mathrm{CO}_{2}$ reduction, the larger the cost to the economy in terms of reduced GNP. However, even in the $20 \%$ reduction case, cumulative GNP losses are relatively small and annual losses do not exceed $2 \%$. These losses, could be largely offset with appropriate tax rebates to consumers.

Quantitative Results:

Detailed quantitative results are provided, including estimates of VMT, MPG, vehicle stock, $\mathrm{CO}_{2}$ emissions, and macroeconomic variables (GNP, investment, imports, etc.).

Peer Reviewed: Not indicated. 
Brinner, R., M. Shelby, J. Yanchar, and A. Cristofaro, Optimizing Tax Strategies to Reduce Greenhouse Gases Without Curtailing Growth, DRI/McGraw-Hill, Lexington, Mass., January 1991, 12 pages.

Mechanisms:

Reduce travel demand

Improve fuel efficiency

Policy Instruments:

Economic incentives (fuel taxes)

Summary:

In this article, the authors estimate the gasoline tax required to stabilize $\mathrm{CO}_{2}$ emissions from light-duty vehicles at their 1989 levels by 2010. The macroeconomic impact of such a tax depends on the utilization of the revenues generated. Three options for recycling the added tax revenues are examined in the article: (1) reduce the Federal deficit, (2) reduce personal income taxes, and (3) reduce the employer-paid portion of payroll taxes. The first option is revenue-raising, while the last two options are called deficit-neutral taxes. The third option is the only one that was found to maintain GNP growth and stabilize $\mathrm{CO}_{2}$ emissions.

The immediate response to increased gasoline taxes is a reduction in VMT. The longer term response is the increase in fleet MPG. Two approaches were used to estimate the responsiveness of MPG to higher gasoline taxes - an econometric model based on demographics and real fuel prices and an engineering model based on manufacturers' costs. Both methods produced similar results: gasoline taxes would need to increase by $\$ 0.45$ per gallon by 2000 and by $\$ 1.30$ per gallon by 2010 in order to increase MPG enough to stabilize $\mathrm{CO}_{2}$ emissions.

The model simulations show that higher gasoline taxes have significant adverse effects in the short run due to increased inflation and reduced household income. Benefits do appear by 2010 with GNP rising above baseline levels as a result of increased national savings, lower credit costs, and higher rates of investment. Although the short-run effect of offsetting income taxes with the revenues generated by the gasoline tax is nearly the same as the revenueraising scenario, GNP falls significantly below baseline levels by 2010 due to higher interest rates and lower business investment. The deficit-neutral scenario of recycling gasoline tax revenues to offset payroll costs was found to have little negative impact on GNP in the short-run and to actually stimulate economic growth (as compared to the baseline) by 2001, resulting in a 5-10\% increase in GNP from 2001 to 2010.

Quantitative Results:

General results from the macro model are presented: GNP, $\mathrm{CO}_{2}$ emissions, and oil imports. Cost-effectiveness is not addressed.

Peer Reviewed: Not indicated. 
Cameron, M., Efficiency and Fairness on the Road, Strategies for Unsnarling Traffic in Southern California, Environmental Defense Fund, Oakland, Calif., 1994, 56 pages plus appendices.

Mechanisms:

Reduce travel demand

Policy Instruments:

Economic incentives (VMT fees, fuel taxes)

Congestion pricing

Summary:

Second in a series of reports addressing transportation problems in Southern California, this study focuses on the equity issues embodied in market-based policies to reduce congestion, improve air quality, and increase the overall efficiency of the transportation system. The initial study advocated such market incentives as VMT, smog, and congestion fees to increase the cost of driving from its current subsidized level (see M. Cameron, 1991, Transportation Efficiency: Tackling Southern California's Air Pollution and Congestion, Environmental Defense Fund and Regional Institute of Southern California, Oakland, Calif., March).

A model for analyzing the short- and long-run impact of market incentive policies on the distribution of transportation costs and benefits was developed. The major finding of this study is that efficiency and equity can be compatible goals and be pursued simultaneously; that is, market-based policies that reduce congestion and improve air quality can be structured so that benefits accrue to people at all income levels.

Market-based incentives have many characteristics that can be varied to achieve specific efficiency and equity objectives. The study illustrates the impact on efficiency and equity of varying such parameters as the type of fee, level of fee, exemptions, and use of revenues, as opposed to proposing any one option. Net benefits associated with each of the measures varied significantly with the proposed use of fee revenues.

Eliminating the subsidized auto-based system through a fee structure that reflects the real cost of driving would ultimately lead to the development of affordable transportation alternatives. This result would benefit low-income people. In the long-run, however, a disproportionate share of the increased travel costs may be imposed on lowincome travelers unless the policies are specifically designed otherwise.

On the basis of the results of the study, policymakers are urged to (1) propose, debate, refine, and implement marketbased policies; (2) focus public agency attention on transportation equity; and (3) identify and promote affordable alternatives to continued reliance on single-occupant vehicle (SOV) travel.

Quantitative Results:

Quantitative results for VMT and various costs and benefits by income group for different fee types are provided in the report. Appendices give detailed descriptions of the models used in the analysis.

Peer Reviewed: Not indicated. 
Deakin, E., "Urban Transportation Congestion Pricing Effects on Urban Form," in Curbing Gridlock: Peak Period Fees to Relieve Traffic Congestion, Volume 2, Committee for Study on Urban Transportation Congestion Pricing, Transportation Research Board, Special Report 242, National Academy Press, Washington, D.C., 1994, 22 pages.

Mechanisms:

Reduce travel demand

Policy Instruments:

Congestion pricing

Summary:

This article examines both theoretical and empirical evidence to help identify the potential effects of congestion pricing on urban form. Two opposing arguments have been made about the relationship between transportation cost and spatial development. The traditional view holds that historic underpricing of transportation services has led to urban sprawl and decentralization. Congestion pricing therefore would correct this underpricing and encourage more compact development. The opposing view holds that congestion pricing would facilitate continued decentralization because (1) it would create a negative image that could stymie business, developer, and consumer interest in locating in those areas with higher transportation costs (especially if competing areas were underpriced) and (2) zoning would prevent higher density development.

Neither location theory nor empirical research on the relationship between the cost of transportation and urban form provide conclusive findings on whether congestion pricing is likely to have a centralizing or decentralizing impact on development. The empirical work indicates that such other factors as housing type, size, and cost; crime rates; and schools are equally as important as transportation in location and land-use decisions.

The possible impact of congestion pricing on urban form is further complicated by distributional effects - who pays the added cost and how revenues are spent - and response by businesses to mitigate any perceived adverse impacts. Examples of possible business intervention are increased subsidies for parking, shifting work schedules to avoid peak periods, and telecommuting. The main implication is that the effect of congestion pricing on urban form is uncertain and context-specific.

Quantitative Results:

Although models and empirical research are discussed, no quantitative results are provided.

Peer Reviewed: Yes. 
DeCicco, J., H. Geller, and J. Morril, Feebates for Fuel Economy, American Council for an Energy Efficient Economy, Washington, D.C., May 1993, 75 pages.

Mechanisms:

Change menu of technologies

Shift consumer choice

Policy Instruments:

Economic incentives (feebate)

Summary:

The authors of this report view improvements in fuel economy as essential to controlling transportation energy consumption and emissions. Feebates, a vehicle pricing policy that directly affects consumers and auto manufacturers, provide a market incentive favoring greater fuel economy. Although data are limited for the United States, the authors provide guidelines on issues that must be considered in developing a workable feebate program (such as adjustments for vehicle size, domestic vs. import, equitable treatment of manufacturers, administrative costs, revenue impacts, inclusion of alternatively fueled vehicles, etc.).

A "dynamic" feebate program that targets future improvements in fleetwide fuel economy is recommended at the federal level, while a "static" feebate program is considered more appropriate at the state level.

The authors propose a size-adjusted feebate program tied to a physically based index of energy efficiency. The proposed feebate addresses the import vs. domestic problem and has separate reference points for cars and light-duty trucks. Several "size" measures are evaluated, and vehicle footprint (wheelbase $\times$ average track width) is selected as the best indicator of vehicle utility. The authors show that it is possible to develop a size-adjusted feebate program that mitigates the domestic vs. import revenue transfer and avoids favoring manufacturers of smaller vehicles.

Limited U.S. experience precludes rigorous estimation of the energy savings attributable to feebates alone; however, the authors expect that significant sales shifts could be induced by feebates if the feebate were as large as existing rebates. Previous studies suggest that consumer-sales shifts account for only a small portion of increased fuel economy (1 MPG). A much greater effect on fleetwide MPG is achieved by sales shifts motivating further fuel efficiency in product planning. Despite the lack of exact estimates of the response to feebates, the authors conclude that a carefully structured program, which takes into consideration the issues raised in their report, could lead to fleetwide fuel economy improvements, thereby reducing energy consumption and $\mathrm{CO}_{2}$ emissions.

Quantitative Results:

Method for calculating feebates and data are provided in an appendix.

Peer Reviewed: Not indicated. 
DeCicco, J., and D. Gordon, Steering With Prices: Fuel and Vehicle Taxation as Market Incentives for Higher Fuel Economy, American Council for an Energy Efficient Economy, Washington, D.C., December 1993, 33 pages.

Mechanisms:

Improve fuel efficiency

Policy Instruments:

Economic incentives (gas guzzler tax, feebates, fuel taxes)

Regulation (CAFE standards)

Summary:

This report examines the effectiveness of pricing policies to reduce light-duty vehicle fuel consumption. The authors cite numerous studies that suggest the dominant response to higher fuel prices is higher fuel economy as opposed to reductions in travel demand (VMT). This response is due to the low fuel-price elasticity of demand. Therefore, the authors focus on policy instruments for improving fuel economy, and they favor regulating/encouraging improved vehicle fuel economy rather than imposing higher fuel taxes.

Fuel and vehicle pricing policy instruments as well as new vehicle fuel economy standards are analyzed. A review of relevant studies and detailed discussions of the effects of the following policy options are provided: fuel pricing policies (gasoline and/or carbon taxes), vehicle pricing policies (the gas guzzler tax, registration fees, and feebates), and fuel economy standards (CAFE).

The authors use estimates from the literature to gauge the effectiveness of the various policy instruments in reducing light-duty vehicle energy consumption in the year 2010 to its 1990 level. To achieve this goal with fuel price instruments alone would require dramatic increases in gasoline prices - $100 \%$ to $200 \%$ - whereas the goal could be met with feebates averaging only 5 to $10 \%$ of vehicle price. The authors conclude that raising fuel economy is the key to reducing transportation energy consumption and emissions, although little improvement is expected in the absence of policy measures or oil supply disruption. Regulation has proven to be a reliable method of achieving fuel economy improvement, but it ignores market forces. Market-based policies such as an expanded gas guzzler tax, feebates, or efficiency-based taxation have been suggested as ways to strengthen fuel economy standards (such as CAFE) while reducing the tension between market forces and regulators.

Quantitative Results:

This report presents quantitative results found in previous studies: price elasticities, response to gas guzzler tax, VMT, fuel costs, etc. No emissions estimates or societal costs are provided.

Peer Reviewed: Not indicated. 
DeCicco, J., et al., "Transportation on a Greenhouse Planet: A Least-Cost Transportation Scenario for the United States" in Transportation and Global Climate Change, American Council for an Energy Efficient Economy, Washington, D.C., 1993, 31 pages.

Mechanisms:

Improve fuel efficiency

Mode shift (increased vehicle occupancy)

Fuel substitution (lower GHG fuel)

Reduce travel demand

Policy Instruments:

Economic incentives (fuel taxes)

Nonmonetary incentives (parking management, improved public transportation)

Summary:

Part of a larger study to develop an end-use-based energy strategy for the United States through the year 2030, this article discusses transportation energy use and $\mathrm{CO}_{2}$ emissions for a single environmental scenario. Significant reductions in petroleum use, overall energy consumption, and $\mathrm{CO}_{2}$ emissions are achieved through improved fuel economy, reduced VMT, and fuel substitution, largely by light-duty vehicles. Freight and air transportation are also included in this study.

Vehicle efficiency improvements are based on a combination of identified technologies plus extrapolations on rates of technical improvement. VMT growth is held to $6 \%$ above the 1990 level, a reduction of $34 \%$ from baseline 2030 VMT. This reduction is accomplished primarily through densification as a result of improved land-use planning and increased use of mass transit as a result of TDM. One-third of the $73 \%$ decline in light-duty-vehicle energy use is attributable to VMT reduction, with the remaining two-thirds coming from improved fuel economy. The mode shift results assume the necessary policy changes to affect land-use patterns and transportation infrastructure.

The results of this study show that technology improvements alone cannot achieve the needed energy reductions, but that they must be accompanied by major changes in transportation and energy policy to encourage a shift away from exclusive automobile reliance toward mass transit and densification. The study also shows that the environmental scenario is cost-effective if energy-related environmental externalities are taken into consideration. Societal cost estimates were available for regulated air pollutants and petroleum security. Therefore, these two were the only external costs included in the study.

Quantitative Results:

This study provides detailed quantitative information, including VMT, fuel economy, technology options, and costs. Summary tables of major results for light-duty vehicles, freight, and air transport are provided.

Peer Reviewed: Not indicated. 
DeCicco, J., Savings from CAFE: Projections of the Future Oil Savings from Light Vehicle Fuel Economy

Standards, American Council for an Energy Efficient Economy, Washington, D.C., May 1992, 39 pages.

Mechanisms:

Improve fuel efficiency

Policy Instruments:

Regulation (CAFE standards)

Summary:

The analysis in this report indicates that strengthening the CAFE standards for light-duty vehicles will result in significant fuel consumption and $\mathrm{CO}_{2}$ reductions. Energy savings relative to a baseline or no-action scenario are projected for five scenarios ranging from CAFE increases of $30 \%$ to $120 \%$ by 2010 . Assumptions used in the forecasts and a description of the methodology are provided.

Since the baseline projection is critical to estimating energy savings, and assumptions about future fuel economy improvements in the absence of regulatory intervention are highly contentious, a middle baseline (with MPG frozen at 1991 levels) was selected, although results are presented for alternative baselines. Energy savings and $\mathrm{CO}_{2}$ emissions reductions are provided for three target years: 2001, 2005, and 2010.

All scenarios show energy savings increasing with the stringency of the standards. One of the five scenarios, a $30 \%$ CAFE increase by 2001 and $60 \%$ increase by 2010 , represents the CAFE improvement needed to offset growth in VMT and keep fuel consumption at year 2000 levels. The $40 \%$ improvement by 2001 and $80 \%$ by 2010 scenario yields reductions in fuel consumption that are $10 \%$ below 1990 levels.

Several factors affecting energy savings are examined, including CAFE credits and trading, rollbacks, floors and ceilings, uncertainties with respect to VMT, the magnitude of the "rebound" effect, fuel economy shortfall, and future fleet composition. The effect of these factors on the overall energy savings estimates was found to be small as compared to the effects of the various baseline assumptions.

$\mathrm{CO}_{2}$ emissions reductions for each of the scenarios, including both tailpipe and "upstream" components, are presented in the report. In addition, hydrocarbon (HC) emissions reductions associated with upstream petroleum processes are estimated.

Quantitative Results:

Energy savings and emissions reductions for each of the target years are provided in both tabular and graphical form. Cost-effectiveness issues are not addressed, and no cost estimates are included in the study.

Peer Reviewed: Not indicated. 
DeLuchi, M.A., Emissions of Greenhouse Gases from the Use of Transportation Fuels and Electricity, Volume I: Main Text, Argonne National Laboratory Report ANL/ESD/TM-22, November 1991.

Mechanisms:

Shift consumer choice

Policy Options:

Economic incentives (higher fuel price)

Research and development (improve performance and decrease cost of new technologies)

Summary:

This report presents estimates of full fuel-cycle GHG emissions from the use of electricity and transportation fuels. The transportation analysis compares $\mathrm{CO}_{2}$-equivalent emissions (in grams per mile) from base-case gasoline and diesel fuel cycles with emissions from alternative-fuel cycles. The alternative fuels included in the study are methanol from coal, natural gas, or wood; compressed or liquefied natural gas; synthetic natural gas from wood; ethanol from corn or wood; liquefied petroleum gas from oil or natural gas; hydrogen from nuclear or solar power; electricity from coal, uranium, oil, natural gas, biomass, or solar energy used in battery-powered electric vehicles; and hydrogen and methanol used in fuel-cell vehicles. The GHGs emitted by motor vehicles include $\mathrm{CO}_{2}, \mathrm{CH}_{4}$, $\mathrm{N}_{2} \mathrm{O}, \mathrm{NO}_{\mathrm{x}}, \mathrm{CO}$, and nonmethane hydrocarbons.

The analysis consists of a total of 30 scenarios that vary assumptions about important input variables from the basecase values. The results of the analysis indicate that the use of fossil fuels to make any transportation fuel does not significantly reduce emission of GHG as long as the transportation fuel is used in an internal combustion engine. Use of natural gas as the ultimate energy source for battery-powered or fuel-cell-powered electric vehicles, however, yielded significant reductions in GHG emissions. The analysis concluded that the largest GHG emissions reductions can be achieved through the use of nonfossil fuels in electric-motor-driven vehicles. The analysis also shows that, while $\mathrm{CO}_{2}$ emissions from combustion are generally the largest motor vehicle contributor to GHG emissions, the other GHGs from combustion and noncombustion sources are in some cases more important to total global warming potential.

The analytical conclusion is that large, long-term reductions in GHG emissions can be best achieved through the use of nonfossil fuels for electricity to charge battery-powered electric vehicles or the use of hydrogen- or fuel-cellpowered electric vehicles. The author makes two policy recommendations to accelerate adoption of alternative-fuel vehicles: full social cost pricing of petroleum fuels and increased research and development to improve the performance and reduce the cost of alternative-fuel vehicles.

\section{Quantitative Results:}

The report provides extensive quantitative information on GHG emissions from a wide range of transportation fuels and is an excellent reference for full fuel-cycle data.

Peer Reviewed: Extensive peer review process. 
Greene, D., Short Term Options for Controlling $\mathrm{CO}_{2}$ Emissions of Light Duty Vehicles, Society of Automotive Engineers (SAE) Technical Paper 901111, SAE Government /ndustry Meeting and Exposition, Washington, D.C., May 1-4, 1990, 15 pages.

Mechanisms:

Improve fuel efficiency

Reduce travel demand

Policy Instruments:

None discussed

Summary:

This paper provides a reference point for $\mathrm{CO}_{2}$ emissions forecasts based on specific automobile and light-truck fueleconomy technologies whose cost-effectiveness, feasibility, and consumer acceptance have been studied extensively by the U.S. Department of Energy (DOE). Five scenarios were formulated to cover a range of possibilities, from no MPG improvement over 1989 to maximum use of available technologies. Three basic MPG scenarios are taken from DOE fuel economy studies: (1) no improvement, (2) the level that is cost-effective at future prices, and (3) the maximum level achievable given available technology. The remaining scenarios address two other possibilities: (1) the reduction in VMT necessary to achieve a $20 \%$ reduction in $\mathrm{CO}_{2}$ from 1989 levels and (2) the deterioration of on-road MPG as urbanization and congestion increase, thus creating a gap between test and on-road fuel economy.

Projections from the five scenarios produce a wide range of fuel use and, equivalently, $\mathrm{CO}_{2}$ emissions forecasts by the year 2015. In all scenarios, fuel economy improves rapidly through 1995 but deteriorates in the baseline by 2000 due to the growing proportion of light trucks in the vehicle fleet.

The results indicate that cost-effective fuel economy improvements could stabilize $\mathrm{CO}_{2}$ emissions through the year 2000 provided that there is no significant deterioration in on-road MPG. Significant reductions in $\mathrm{CO}_{2}$ emissions, however, are likely to require reductions in VMT in addition to the maximum fuel economy. VMT reductions are both difficult and costly in terms of economic welfare. For example, gasoline prices must increase to $\$ 3.90 /$ gal by 2005 to reduce VMT to the level necessary to achieve the goal of $20 \%$ reduction in $1989 \mathrm{CO}_{2}$ emissions. The scenario that considers a widening gap between on-road and test MPG is particularly disturbing. The results, which are consistent with current urbanization and congestion trends, show a 50\% increase in fuel use and a return to 1990 fleet fuel economy levels by 2015 , which would make it difficult to even stabilize $\mathrm{CO}_{2}$ emissions.

Quantitative Results:

Quantitative results for $\mathrm{CO}_{2}$ emissions and fuel use are given for each scenario. Assumptions on fuel price, MPG, and fuel economy improvement costs are also provided. No data on cost-effectiveness or societal costs are given.

Peer Reviewed: Not indicated. 
Greene, D., "Vehicle Use and Fuel Economy: How Big is the 'Rebound' Effect," The Energy Journal, 13 (1): 117-143, 1992, 27 pages.

Mechanisms:

Improve fuel efficiency

Policy Instruments:

Regulation

Summary:

The objective of the analysis is to determine the magnitude of the "rebound" effect - the response in VMT to reduced fuel costs of travel or, alternatively, increased vehicle efficiency. The size of the rebound effect is a main determinant of the relative effectiveness of technology-based versus price-based policy initiatives to reduce emissions. The key factor is the sensitivity of VMT to changes in fuel costs (elasticity). The author presents a review of the relevant literature (estimates of VMT, including fuel cost per mile as an independent variable) before describing his approach.

The analysis uses an econometric model to explain VMT as a function of GNP, fuel cost per mile (real price of gasoline divided by MPG), number of licensed drivers, and possibly the lagged dependent variable. Statistical analyses are performed on the various model specifications and error structures to determine the "best" formulation. The analysis uses data for light-duty VMT over the 1966-1988 time period.

The study concludes that VMT is insensitive to fuel costs per mile, i.e., that the elasticity is small. Fuel costs account for a relatively small share of the variable and total cost of travel when the traveler's time cost is included. In addition, the sensitivity is found to decrease over time with no measurable long-run effect - any significant impact of fuel cost on VMT takes place during the first year.

The evidence presented in this analysis suggests that the rebound effect is small, between 5 and $15 \%$, implying that technology-based fuel improvements would be 85 to $95 \%$ effective in reducing gasoline consumption. Note that these results also imply that fuel taxes would have to be quite large to reduce VMT.

Quantitative Results:

The study presents quantitative information on the statistical relationship between VMT and fuel cost per mile. Emissions reductions and cost-effectiveness issues are not discussed.

Peer Reviewed: Per journal policy. 
Gushee, D., Potential Policy Levers for Alternative Fuels: Costs, Energy Security, and Environmental Impacts, Congressional Research Service, Washington, D.C., April 1992, 17 pages.

Mechanisms:

Fuel substitution (lower GHG fuel)

Policy Instruments:

Regulation

Research and development

Economic incentives (subsidies)

\section{Summary:}

This report represents the Congressional Research Service's response to a request from the Alternative Fuels Council to provide a ranking of different policy levers to encourage alternative fuels on the basis of cost, energy security, and environmental benefits. For each of the fuels considered (methanol, ethanol, natural gas, propane, and electricity), the study identifies the critical path for commercialization and the obstacles that might be overcome by governmental policy instruments. The goal for each fuel is $5 \%$ of vehicle fuel consumption by 2010 with an interim goal of $5 \%$ of new vehicles by 2001 .

The study describes the effect of several cost factors on the commercialization and market penetration of alternative fuels. Cost factors include fuel cost, vehicle cost, fuel transportation cost, and retail distribution cost. The alternative fuels were then evaluated on the basis of energy security and environmental impacts, including GHG.

A major conclusion of the study is that costs, benefits, and appropriate policy actions vary by energy form; no single set of policy levers applies to all alternative fuels. In addition, the pace of market penetration greatly influences the relative rankings of the alternative fuels. The two leading candidates for significant near-term (within 10 years) market penetration are methanol and ethanol. Alcohol fuels are less costly for vehicle manufacturers, are more easily accepted by consumers, and can utilize the existing fuel delivery infrastructure. The other alternative fuels would require a longer penetration time. The market penetration for natural gas and propane could be accelerated through the dual-fueled vehicle, but the environmental advantage of natural gas and propane would be compromised. Electric vehicles are the most expensive option and the most difficult to accelerate.

Quantitative Results:

No modeling is conducted, but quantitative information is presented.

Peer Reviewed: Not indicated. 
Haltmaier, S., The Replacement of Transportation Subsidies with Optimal Highway Pricing and Investment, DRI/McGraw-Hill for U.S. Environmental Protection Agency, Lexington, Mass., May 1994, 18 pages.

Mechanisms:

Reduce travel demand

\author{
Policy Options: \\ Congestion pricing (light-duty vehicles) \\ Economic incentives (fees based on weight per axle for heavy-duty trucks)
}

Summary:

The basic premise of this study originates from the economic theory of public goods. Historically, such transportation services as road construction, highway maintenance, and parking have been financed through various user fees (e.g., vehicle registration and fuel taxes) and other general revenue sources (e.g., property taxes, bond issues, and investment income). Since consumers pay less than the full economic cost (market plus external) of transportation services, travel demand exceeds the socially optimum level. The issue, therefore, is whether optimal pricing of transportation services, which would reflect total economic costs, can be expected to lead to reductions in GHG emissions. The article is inconclusive, largely because of the lack of quantitative work in this area.

According to the author, an optimal pricing and investment system for transportation services would recognize two distinct costs: road wear and congestion. Heavy vehicle loadings, the primary cause of road wear, would be charged weight-per-axle fees adjusted for miles traveled by type of road, while passenger vehicles, the main contributor to congestion, would be subject to time-of-day pricing. Optimal pricing would also include a VMT charge to cover general highway services (e.g., law enforcement and fire protection) and a parking price "cash out" to monetize the fair market value of employee parking.

Although these strategies may be more representative of costs, the impact on GHG emissions remains uncertain. For example, while weight-per-axle fees reduce vehicle loadings, they do not necessarily reduce fuel consumption. For light-duty vehicles, the increase in nonpeak miles traveled could offset the reduction in peak demand, mitigating any $\mathrm{CO}_{2}$ benefits. The article explores the issue of optimal pricing as a possible GHG reduction strategy, but it does not provide conclusive results.

Quantitative Results:

No quantitative analysis was conducted, but results from other transportation-sector cost and financing studies are presented.

Peer Reviewed: Yes. 
Harvey, G., "Transportation Pricing and Travel Behavior," in Curbing Gridlock: Peak Period Fees to Relieve Traffic Congestion, Volume 2), Committee for Study on Urban Transportation Congestion Pricing, Transportation Research Board, Special Report 242, National Academy Press, Washington, D.C., 1994, 26 pages.

\section{Mechanisms:}

Reduce travel demand (VMT and trips)

Mode shift

Policy Instruments:

Congestion pricing (tolls)

Transit fares

Summary:

This article summarizes current knowledge about the effects of transportation pricing on daily activities and travel behavior. In particular, the author evaluates the feasibility of drawing generalizable conclusions from specific past experience with transportation pricing.

In the area of price sensitivity, one is able to conclude from the empirical evidence on tolls and bridges, transit fares, fuel prices, and parking fees that trip-making is only weakly responsive to price, even for commuting trips. Estimates of elasticity range from moderately to highly inelastic in most situations; e.g., the elasticity for toll increases ranges from -.05 to -.20 .

The case study approach, however, does not provide such generalizable conclusions about distributional effects of transportation pricing, since responses are dependent on a variety of factors that are context-specific. Contextspecific parameters that influence response include the geographic scale of implementation, network topology, magnitude of existing congestion, availability of alternative modes, and social-demographic composition.

Gaining insight into the likely effects of congestion pricing is further complicated by the lack of empirical data on peak-pricing of transportation services. In addition, the wide range of potential travel responses increases the uncertainty and variability associated with predicting impacts. Travel decisions that could be influenced by price changes include choice of route, destination time, and mode; trip frequency and activity selection; chaining or trip linking; and automobile ownership.

Quantitative Results:

Model results from two recent studies of congestion pricing for California's South Coast Air Basin and Bay Area are provided in the article. The model estimates the effects of congestion pricing on VMT, trips, and emissions.

Peer Reviewed: Yes. 
Johnson, E., Avoiding the Collision of Cities and Cars: Urban Transportation Policy for the Twenty-First Century, American Academy of Arts and Sciences, Chicago, Ill., 1993, 58 pages.

\author{
Mechanisms: \\ Reduce travel demand (mass transit, carpooling) \\ Improve fuel efficiency \\ Fuel substitution (lower GHG fuel)
Policy Options:
Economic incentives (fuel taxes, ZEV subsidies)
Regulation (land use, manufacturer requirements, inspection and maintenance programs with stiff fees for high-emitting vehicles)

Summary:

Sponsored by the National Academy of Arts and Sciences, in cooperation with the Aspen Institute, this study recommends strategies to minimize auto-related social costs, provide efficient transportation, and develop more livable cities. The central hypothesis of the report is that long-term strategies for changing mobility structures and land-use patterns can only be achieved if they are preceded by pricing and other habit-changing strategies that reflect the true cost of vehicle use. Unpriced and underpriced vehicular travel have led to the overuse of automobiles and an auto-dependent urban infrastructure. Driven by the central hypothesis, the report recommends (1) near-term habitchanging strategies, (2) mid-term technology changing strategies, and (3) long-term strategies for changing mobility structures and land-use patterns.

Near-term recommendations include pricing strategies and mandates aimed at encouraging socially responsible vehicle use. Four pricing strategies are proposed: congestion pricing, higher fuel taxes, equal tax treatment for all commute modes, and incentives to repair or retire high-polluting vehicles. The study also recommends strengthening laws to detect and deter drunk driving and more stringent controls on access to drivers licenses. Faced with the full social cost of vehicle use, drivers will tend to shift to cleaner, more fuel-efficient cars, reduce driving during peak periods, and eliminate trips or shift to alternative modes.

This change in travel behavior provides the prerequisite foundation for mid-term strategies to improve vehicle, fuel, and infrastructure technology. Specifically, market incentives to encourage the development and introduction of ultralight electric vehicles and Intelligent Vehicle Highway Systems (IVHSs) are proposed. By transforming the mix of urban vehicles, this second set of strategies should reduce air pollution, increase energy security, and improve the quality of urban life. Unlike strategies that target vehicle use, the study suggests that technology-forcing strategies would be best implemented at the Federal level.

The long-term strategies, viable in the new cost environment established by the near- and mid-term recommendations, seek to change urban mobility structures and land-use patterns in order to moderate mobility needs. Enhanced public transit and intermodal systems would allow each mode to be exploited for its comparative advantages. The report recommends that changes in zoning accompany improvements in public transit and intermodalization so that mixed-use, transit-oriented developments can be built.

Quantitative Results:

No modeling; little quantitative information is contained in the report.

Peer Reviewed: Extensive peer review. 
Jones, C., "Another Look at U.S. Passenger Vehicle Use and the 'Rebound' Effect from Improved Fuel Efficiency," The Energy Journal, 14 (4): 99-110, 1993, 12 pages.

Mechanisms:

Improve fuel efficiency

Policy Instruments:

Regulation

Summary:

This study revisits the Greene analysis of the "rebound" effect by examining the relationship of VMT and fuel cost per mile using an alternative model specification. The results confirm the Greene findings that the short-run effect is small (less than $13 \%$ ), but they refute or, at a minimum, call into question, the insignificance of the long-run adjustment process.

The author focuses on the lagged dependent variable since that model cannot be rejected for purely statistical reasons. The lagged dependent model yields a significant long-run rebound effect, but it is problematic from a theoretical perspective, since the estimated coefficient for GNP is small and insignificant. While all coefficients in the model specification preferred by Greene have the correct signs and are statistically significant, the author found that this model had a worse "fit" in terms of statistical diagnostics.

This analysis concludes that some of the evidence suggests that there may be a significant long-run rebound effect.

Quantitative Results:

The study presents quantitative information on the statistical relationship between VMT and fuel cost per mile. Emissions reductions and cost-effectiveness issues are not discussed. Detailed theoretical discussion of model specification is presented.

Peer Reviewed: Per journal policy. 
Krupnick, A., M. Walls, and C. Collins, "Global Warming and Urban Smog: The Cost-Effectiveness of CAFE Standards and Alternative Fuels," The Energy Journal, 14 (4): 75-97, 1993, 23 pages.

Mechanisms:

Improve fuel efficiency

Fuel substitution (lower GHG fuel)

Policy Instruments:

Regulation (CAFE standards)

Summary:

The authors analyzed the cost-effectiveness of two mechanisms for reducing GHG: increasing the CAFE standards and substituting alternative fuels (compressed natural gas [CNG]), methanol, and reformulated gasoline) for gasoline. In addition to the base case, the analysis provides "most likely" and "optimistic" estimates of emissions and costs for the year 2000. Emissions are estimated for each stage of the fuel cycle: feedstock extraction and transport, fuel processing or refining, fuel distribution, and fuel combustion for each of the fuel types. Total cost estimates are obtained for each vehicle type and scenario. Cost estimates corresponding to increases in the CAFE standards are the most controversial. As compared to Duleep's estimate (see National Research Council, 1994, Automotive Fuel Economy, How Far Should We Go?, National Academy Press, Washington, D.C.), the authors assume a relatively high cost for their "most-likely" scenario as a way to capture some of the nonpecuniary (performance and driveability) costs. Joint impacts on global warming and urban ozone are calculated as the cost per ton of $\mathrm{CO}_{2}$ equivalent net of volatile organic compound (VOC) reduction benefits. In addition, the analysis incorporates the "rebound" effect - the impact on VMT of increased fuel efficiency.

Substituting CNG for gasoline has the lowest adjusted (for VOC benefits) cost per ton of GHG for both mechanisms (with and without the rebound effect), followed by increasing CAFE standards, substituting methanol for gasoline, by and substituting reformulated for conventional gasoline. Reformulated gasoline requires more energy to refine than conventional gasoline, leading to higher $\mathrm{CO}_{2}$ emissions.

The cost-effectiveness rankings remain the same for all alternatives: with and without VOC benefits and with and without the rebound effect. Excluding the rebound effect, however, does have a significant impact on CNG, CAFE, and methanol cost estimates - it lowers the CNG and CAFE estimates and increases the methanol estimate, thereby leading to a wider gap among them.

Quantitative Results:

Cost-effectiveness estimates are provided; only changes in VMT are accounted for, not societal costs.

Peer Reviewed: Per journal policy. 
Loudon, W., D. Dagang, and R. Dulla, The Effectiveness of Transportation Control Measures in Reducing Congestion and Improving Air Quality, Air \& Waste Management Association, 86th Annual Meeting \& Exhibition, June 1993, 16 pages.

\title{
Mechanisms:
}

Reduce travel demand (number of trips and VMT)

Improve system efficiency

\author{
Policy Instruments: \\ Nonmonetary incentives (rideshare, alternative work schedules, traffic-flow improvements, \\ land-use management) \\ Economic incentives (subsidies) \\ Regulation
}

\section{Summary:}

This article describes a screening methodology for TCMs based on their effectiveness with respect to travel demand and emissions reduction $\left(\mathrm{HC}, \mathrm{CO}\right.$, and $\mathrm{NO}_{\mathrm{x}}$ ). The article presents results from two applications of the methodology developed. The objective of the first project, sponsored by the California Department of Transportation, was to predict the impact of TCMs on travel behavior and pollutant emissions and to evaluate the cost-effectiveness of the measures. The Federal Transit Administration and the City of Pleasanton, sponsors of the second project, required detailed information on the cost-effectiveness of employer-based measures from the employer's perspective.

The model estimates the impact of TCMs on the number of vehicle trips, VMT, and speed for 1990 through 2010. The changes in travel parameters are then used to calculate emissions, costs, and cost-effectiveness indices. The results indicate that the single most important travel parameter affecting emissions is "trips". According to this study, measures that are effective in eliminating trips should be the focus of air-quality plans.

Although highly dependent on the specific employer and site location, the analysis also showed that, from the employer's perspective, the most cost-effective measure for improving air quality was a reduction in employersubsidized parking. The least cost-effective measures were found to be home-based telecommuting and those measures that required payments by the employers to the employees, such as transit-pass subsidies, direct monetary incentives, and transportation allowances.

Quantitative Results:

Results are presented graphically. The article does not provide any data tables.

Peer Reviewed: Yes. 
MacKenzie, James J., The Keys to the Car: Electric and Hydrogen Vehicles for the 21st Century, World Resources Institute, May 1994, 128 pages.

Mechanisms:

Shift consumer choice

Change menu of technologies

\author{
Policy Instruments: \\ Economic incentives (fuel taxes, tax credits) \\ Research and development (ZEVs)
}

Summary:

The main thrust of this book is that the long-term solution to the environmental, energy security, and economic problems of the United States is the gradual (over the next three to four decades) substitution of ZEVs for oil-fired internal combustion engines. Following a detailed analysis of alternative fuels (CNG, ethanol, and methanol), the author concludes that the benefits of shifting to any of these fuels do not justify the cost. While substituting alcohols for gasoline reduces national security risks, it would not significantly reduce ozone levels or slow global warming. $\mathrm{CNG}$ vehicles emit less $\mathrm{CO}_{2}$ than gasoline vehicles, but, because of the large methane component, $\mathrm{CNG}$ use would reduce GHGs only slightly. Electric vehicles, if fueled by electricity produced from natural gas or the current mix of fuel sources, emit only half the amount of $\mathrm{CO}_{2}$ as gasoline vehicles.

For at least the next ten years, ZEVs must be battery-powered. Beyond that time, new technologies (such as hydrogen fuel cells, flywheels, and ultracapacitors) can be phased in. The author recommends four policy shifts to expedite the market penetration of electric vehicles: (1) fuel price reform, (2) enhanced support of research and development (R\&D), (3) infrastructure development, and (4) stimulation of fleet purchases.

The recommendations are aimed at both stimulating demand and encouraging supply. If gasoline taxes were raised by $\$ 0.50 /$ gal to cover the full cost of driving, then EVs would become competitive. In the absence of increased fuel prices, the author recommends technology-forcing legislation like the EV program in California. Shared-cost R\&D would increase the likelihood that such new technologies as hydrogen fuel cells, flywheels, and ultracapcitors will become commercially viable. Prior to significant market acceptance, there is a need to develop the supporting infrastructure for recharging EVs. Further research is needed, however, to determine the optimum network for vehicle refueling and hydrogen production, distribution, and storage. Tax credits, deductions, and other monetary incentives targeting fleet owners would significantly speed market penetration.

Quantitative Results:

Limited quantitative information is presented.

Peer Reviewed: Not indicated. 
Magid, L., Breaking Out of the Automobile Box: Achieving Automobile Policy Goals Through Cooperation Between U.S. Auto Manufacturers, Environmental, and Consumer Groups, Kennedy School of Business, Harvard University, April 1994, 40 pages.

Mechanisms:

Improve fuel efficiency

Policy Instruments:

Accelerated vehicle scrappage program

Summary:

This study looks at three case studies of cooperative private partnerships between traditionally adversarial stakeholders in the automobile regulatory debate. The case study of General Motors Corp. (GM) and the Environmental Defense Fund (EDF) partnership is particularly germane to formulating policy goals to reduce GHG emissions. The GM-EDF agreement lists ten possible areas of discussion, two of which are discussed in the article. The author uses examples, one of successful cooperation and one where the partnership failed to reach agreement, to draw conclusions about factors that are critical to success of the partnership and about how government policies can influence the cooperative solution process.

The Mobile Emissions Reduction Crediting (MERC) program, approved in pilot form by the EPA, represents a result of successful GM-EDF collaboration. Under the MERC program, emissions credits generated by the accelerated retirement of high-emitting vehicles can be traded between mobile and stationary sources, achieving more rapid compliance at lower cost than through separate regulation of mobile and stationary sources. The success of this particular collaboration stems from a common goal: the development of market-based mechanisms for regulating and reducing mobile-source emissions. Both GM and EDF share a common vision that economic incentives provide more efficient environmental solutions than regulation.

GM and EDF failed to reach agreement on the proposed phase-out of chlorofluorocarbons (CFCs) due to fundamental differences about the costs to the environment and benefits to consumers as a result of CFC use. This example illustrates that a shared vision of the best method for addressing environmental issues is not sufficient to generate cooperation when basic differences in underlying values exist.

The case studies indicate that government policy affects the character and success of stakeholder partnerships in a variety of ways. Government can facilitate cooperation by clearly defining the problem to be addressed, establishing goals, disseminating information, and providing a supportive political environment.

Quantitative Results:

No quantitative information is contained in this study.

Peer Reviewed: Not indicated. 
Miles-McLean, R., S. Haltmaier, and M. Shelby, "Designing Incentive-Based Approaches to Limit Carbon Dioxide Emissions from the Light-Duty Vehicle Fleet," Chapter 4 in Transportation and Global Climate Change, American Council for an Energy-Efficient Economy, Washington, D.C., 1993, 18 pages.

Mechanisms:

Improve fuel efficiency

Policy Instruments:

Economic incentives (gas guzzler tax/gas sipper rebate, fuel taxes, oil import fee)

Summary:

The analysis in Chapter 4 focuses on three incentive-based policy options to stabilize or reduce $\mathrm{CO}_{2}$ emissions from gasoline light-duty vehicles: a gasoline tax, a gas guzzler tax/sipper rebate program, and an oil import fee. Econometric models are used to analyze the impact on macroeconomic activity and energy demand of these three carbon-emission-control policies. In the transportation module, fuel consumption is estimated for four vehicle types (passenger cars and light-, medium-, and heavy-duty trucks) on the basis of demand for travel and consumers' vehicle preferences, assuming a fixed travel budget constraint. Two different approaches, an econometric model and an engineering model, were found to yield similar projections of MPG responsiveness to gasoline prices. The costeffectiveness of each of the three policy options is evaluated for achieving the goal of reducing $\mathrm{CO}_{2}$ emissions to their 1989 level by the year 2000 and then maintaining that level through 2010 .

The analysis demonstrates that incentive-based policies to reduce $\mathrm{CO}_{2}$ can be designed with minimal long-term costs to the U.S. economy. Of the options considered, the gasoline tax was found to be the most cost-effective policy for reducing $\mathrm{CO}_{2}$ emissions, since the tax is directly proportional to carbon emissions. The analysis shows that the broad-based oil import fee is the least desirable method for reducing $\mathrm{CO}_{2}$ emissions, since it would encourage substitution.of coal for oil in the electric utility and industrial sectors.

The gas guzzler/sipper program leads to a more fuel-efficient vehicle stock sooner and at less cost than the other options, but it leads to higher VMT and fuel consumption through the rebound effect. In addition, the guzzler/sipper program has the largest impact on the vehicle size mix and import share as consumers shift to smaller vehicles.

Quantitative Results:

Major results from the scenario analysis are presented in tables and graphs, including the impact on macroeconomic activity, new-car MPG, size mix, and import share. Societal costs are not included in the analysis.

Peer Reviewed: Not indicated. 
National Research Council, Automotive Fuel Economy: How Far Should We Go?, National Academy Press, 1992, 259 pages.

Mechanisms:

Improve fuel efficiency

Reduce travel demand

Policy Instruments:

Regulation (CAFE standards)

Economic incentives (higher fuel prices, feebates)

Summary:

The National Research Council, at the request of the National Highway Traffic Safety Administration and Federal Highway Administration, estimated "technically achievable" fuel economy for passenger cars and light-duty trucks. Three assumptions underlie technical achievement: (1) new vehicles comply with Tier I emissions standards, (2) no degradation in vehicle characteristics (e.g., performance and interior volume), and (3) technologies considered are currently produced somewhere in the world and "pay for themselves at gasoline prices of between $\$ 5$ and $\$ 10$ per gallon or less" (p. 2). Using technological and cost data, estimates (upper bound) of technically achievable fuel economy for the year 2006 range from 44 MPG for subcompacts to 25 MPG for large pickup trucks.

The study concludes that higher fuel economy standards should be accompanied by market-based incentives (higher fuel prices and/or cash rebates) to induce increased demand for fuel-efficient vehicles. Internalizing costs associated with fuel consumption would influence purchase decisions and travel behavior consistent with societal goals (fuel economy and emissions). Current trends in consumer demand, including an aging vehicle population, increased demand for safety and high performance, and increased purchases of light trucks, however, are in opposition to improved fleet fuel economy.

The divergence between CAFE standards and market signals have diminished the regulation's effectiveness and increased costs. Moreover, current CAFE standards disadvantage domestic full-line manufacturers and enhance the competitive position of imported cars. Assuming the CAFE system is retained, the study recommends bringing fuel economy requirements for light trucks into conformance with those for automobiles, in view of their increasing market share. Although other policy instruments, such as infrastructure improvements, intelligent-vehicle highway systems, speed limits, and carpooling, were mentioned, they were considered secondary.

Quantitative Results:

Technological and vehicle cost information are provided.

Peer Reviewed: Extensive review process. 
Office of Technology Assessment (OTA), U.S. Congress, Changing By Degrees: Steps to Reduce Greenhouse Gases, Washington, D.C., February 1991, 354 pages.

\section{Mechanisms:}

Reduce travel demand (VMT)

Improve vehicle efficiency

Improve system efficiency

Policy Instruments:

Economic incentives (fuel tax or sales/registration tax based on MPG, rebates for new fuel-efficient vehicles)

Regulation (fuel economy standards)

Summary:

This analysis focuses on technical options to decrease $\mathrm{CO}_{2}$ emissions in the near term ( 25 years) for six key sectors of the economy: Buildings, Transportation, Energy Supply, Manufacturing, Forestry, and Food. A general energy accounting model was developed to estimate emissions under three alternatives: Base case or no policy intervention scenario, a Moderate scenario that imposes little or no economic costs, and a Tough case that reduces transportation $\mathrm{CO}_{2}$ emissions by $10 \%$ of 1987 levels.

The major reductions for the transportation sector come from higher auto and truck efficiency, better control of traffic speed, and, under the Tough scenario, improved public transit.

The OTA study assumes that petroleum will remain the fuel of choice for passenger and freight modes through 2015. While considered a means for reducing urban air pollution, alternative fuel vehicles do not necessarily reduce GHG emissions.

Quantitative Results:

The assessment provides quantitative results on VMT reductions, operating efficiencies, $\mathrm{CO}_{2}$ emissions, and costs (particularly the cost-effectiveness of various measures).

Peer Reviewed: Yes. 
Office of Technology Assessment, U.S. Congress, Saving Energy in U.S. Transportation, report OTA-ETI-589, July 1994, 266 pages.

Mechanisms:

Improve travel demand (VMT)

Change menu of technologies (improve fuel efficiency and lower GHG fuel)

Policy Options:

Economic incentives (gasoline tax, subsidies, feebates)

Public investment in transportation infrastructure

Regulation (efficiency standards, zoning)

Nonmonetary incentives (parking charges, HOV lanes, "smart" highways)

Summary:

This report focuses on transportation energy use, describes an array of policies designed to reduce that use, and evaluates the effect of these policies on such transportation problems as congestion and air pollution. Current transportation energy use and consumption trends are described. Nearly all of the forecasts presented estimate transportation energy growth between 1990 and 2010 to be lower than historic levels because of lower VMT growth (less than 2\%) and increased efficiency. In the absence of significant changes in energy policy, OTA believes that these projections are likely to underestimate actual transportation energy growth.

The efficiency of the U.S. transportation system is compared to that of Western Europe in light of statistics that show that Americans consume about three times more energy in transportation. Half of this disparity in transportation energy use is due to the difference in travel volumes: per-capita miles traveled by Americans is nearly double that of Europeans. The other half of the difference can be attributed to differences in energy efficiency (such as modal shares, load factors, and vehicle efficiency).

Inefficient pricing and externalities have led to automobile overuse and contributed to air pollution and congestion. As part of this study, Mark DeLuchi (University of California at Davis) estimated that motor vehicle users pay for only about one-half to two-thirds of the social costs of motor vehicle use, indicating that there is significant potential for policymakers to improve the economic efficiency by "internalizing" the cost of transportation.

Policy options for transportation energy conservation include economic incentives (gasoline tax and feebates), public investment (R\&D, mass transit, improved infrastructure), and regulatory incentives (efficiency standards, zoning, fuel use requirements, and inspection and maintenance). Which policy options are "best" depends on the objective and the perceived urgency of the problem. For example, there is general agreement that air pollution is an immediate concern but less agreement on the urgency of reducing GHG emissions.

The report identifies a wide range of policy options and evaluates their likely impact on travel demand, energy use, emissions, and economic security. The study does not recommend a particular approach for transportation energy conservation; rather it provides an analysis of the issues and policy options to assist policymakers in formulating a strategy consistent with their goals.

Quantitative Results:

The report is basically qualitative. Quantitative data are presented as needed to support the text.

Peer Reviewed: Extensive peer review process. 
Organization for Economic Co-Operation and Development, Cars and Climate Change, Paris, France, 1993, 235 pages.

Mechanisms:

Improve fuel efficiency

Fuel substitution (lower GHG fuel)

Policy Instruments:

Economic incentives (fees/subsidies)

Regulation

Summary:

This report considers two strategies for reducing GHG emissions in the transportation sector: improved fuel efficiency and alternative fuels. These options are evaluated on the basis of life-cycle emissions by using a model that includes technical, market, and economic potential. Fuel-supply emissions are estimated for extraction, transport, processing, and fuel distribution activities. Similarly, the model calculates GHG emissions from all stages of vehicle production, although exhaust emissions account for nearly $75 \%$ of the total.

The potential for fuel economy improvement is greatest in two areas: increasing the efficiency of the drivetrain (engine, transmission, and axles) and reducing the tractive effort needed to move the vehicle (by reducing vehicle weight and drag). Potential fuel economy improvements of between 10 and $20 \%$ are estimated for the fleet as a whole over the next 20 years.

Life-cycle GHG emissions are calculated for a wide range of fuels including: reformulated gasoline, diesel, natural gas, liquified petroleum gas (LPG), electricity, and alcohol. Although comparatively limited in terms of emission reduction potential, the study suggests that diesel and compressed natural gas (CNG) may result in lower emissions at lower cost than the alternatives. Diesel cars have the potential to reduce GHG emissions by nearly $30 \%$, while CNG cars, even assuming optimal production with respect to GHG emissions, offer only a $10 \%$ reduction potential.

Because of their financial attractiveness and widespread availability, diesel and CNG were selected for a more detailed cost comparison with gasoline vehicles. This analysis indicates that the total cost of driving increases by less than $10 \%$ as a result of switching from gasoline to diesel or CNG. Drivers who travel more than the average annual distance would find diesels more cost-effective than gasoline engines due to higher durability. In addition, CNG vehicles were found to be cheaper than gasoline; however, consumers must be willing to accept a shorter range between refuelings.

Since $\mathrm{CO}_{2}$ emissions are directly linked to fossil fuel demand, an international carbon tax would be the most efficient abatement measure, but it is considered politically infeașible. Such indirect measures as fuel economy standards, transportation demand management, and incentives to reduce vehicle power/weight ratios will reduce energy use and, thereby, GHG emissions, but they will have little effect on the attractiveness of fuel switching. The report suggests that the penetration of alternatively fueled vehicles could be accelerated through reducing the uncertainty in fuel price and fuel supply infrastructure.

Quantitative Results:

Extensive data and quantitative information are provided in the report, particularly with respect to emissions and cost.

Peer Reviewed: Not indicated. 
Public Policy Program, UCLA Extension, Overview of Strategies for Making Connections Between Transportation, Land Use, and Air Quality, Summary of Proceedings, Annual Symposium Series on the Transportation, Land Use, Air Quality Connection, Los Angeles, Calif., November 6-8, 1991, 16 pages.

Mechanisms:

Reduce travel demand (number of trips and VMT)

Improve system efficiency

Improve operating efficiency

Fuel substitution

\author{
Policy Instruments: \\ Regulation \\ Economic incentives (subsidies/taxes) \\ Nonmonetary incentives
}

Summary:

This report summarizes the key presentations and findings of the symposium. The presentations covered four main categories of mitigation strategies: technical fixes, transportation investment, command-and-control regulations, and market-based regulations.

Technical fixes encompass new car emission standards, low emission fuel, and vehicle emissions inspections. The consensus from symposium participants was that, while these measures are very powerful, concerns about cost and feasibility exist. None of the participants felt that transportation investment (new highways and transit systems) would have a significant impact on air quality. Participants also had serious doubts whether institutions responsible for transportation-control measures (demand management) and indirect-source (land use) regulations (ISRs) had the will or the ability to bring about the desired changes in travel behavior and real estate development. Political feasibility was seen as the major obstacle to such market-based proposals as "cash-out" parking pricing. Detractors of market-based mechanisms pointed to their inequity, while proponents noted that these mechanisms could be structured to be progressive or neutral.

Three different approaches to transportation planning for air-quality improvement were represented at the symposium: (1) least cost, least inconvenience; (2) comprehensive behavior alternative: and (3) limited behavior alternative. Advocates of each of these approaches have different values, which leads to differences in the evaluation of costs and benefits and thus widely divergent policy prescriptions.

Many of the effects of TCMs and ISRs are uncertain, particularly when the indirect effects are taken into consideration. This area requires further research, along with empirical analysis of market-based measures.

Quantitative Results:

This document contains no original research or modeling; therefore, no quantitative results are presented.

Peer Reviewed: Not indicated. 
Public Policy Program, UCLA Extension, The Role of Land Use Strategies for Improving Transportation and Air Quality, Summary of Proceedings, Annual Symposium Series on the Transportation, Land Use, Air Quality Connection, Los Angeles, Calif., November 7-9, 1993, 35 pages.

Mechanisms:

Reduce travel demand (number of trips and VMT)

Improve system efficiency

Increase vehicle occupancy

Improve fuel efficiency

Policy Instruments:

Regulation

Economic incentives (subsidies/taxes)

Congestion pricing

Nonmonetary incentives (parking management)

Summary:

This report summarizes the key presentations and discussions of the symposium. Topic areas included an overview of land-use strategies for improving transportation and air quality, the feasibility of and mechanisms for transitoriented and pedestrian-oriented development, travel behavior effects of transit-oriented development, and the impact of future transportation technologies and land-use policies on air quality.

Several discussions focused on the ability of land-use regulation to have a significant impact on travel behavior and air quality. While land-use regulation is considered to be more feasible politically than market-based strategies, landuse patterns are well-established and change slowly. More research is needed to determine the effectiveness of landuse controls in reducing emissions.

Parking requirements, zoning regulations, and quality of life were among the major issues discussed in connection with transit-oriented and pedestrian-oriented development. In general, participants favored developments providing choices in housing type and living environment, along with choices in travel modes. Educating decision makers and families about mixed-use development was seen as a way to reduce the institutional, political, and economic barriers encountered by transit-oriented development. Several parking reform options were discussed, including reduction in minimum parking requirements, cash-out pricing and shared parking arrangements. Skepticism was raised over the political feasibility of the parking reform measures as well as their ability to affect travel-demand decisions and significantly improve air quality.

Although people are more aware of the connection between transportation, land use, and air quality than in the past, debate arose over the political feasibility of policy options that address only air quality. At least two presenters claimed that air quality per se does not interest the public or decision makers and that to gain widespread support, it should be placed in the context of traffic congestion.

Telecommuting, "smart" highways, and alternative fuel vehicles were among the topics discussed in connection with future transportation technologies. Congestion pricing also surfaced in these sessions as a tool that could be used in conjunction with land-use planning and TDM programs.

Quantitative Results:

This document contains no original research or modeling; therefore, no quantitative results are presented.

Peer Reviewed: Not indicated. 
Repetto, R., R. Dower, R. Jenkins, J. Geoghegan, Green Fees: How a Tax Shift Can Work for the Environment and the Economy, World Resources Institute, November 1992, 96 pages.

Mechanisms:

Improve system efficiency (reduce congestion)

Reduce travel demand

Policy Instruments:

Congestion pricing

Economic incentives

Summary:

Following a brief review of the economic theory of taxes and their effect, the authors address, in general, the impacts of environmental taxes and other incentive-based policy instruments to reduce environmentally damaging activities. According to economic theory, when there are many parties contributing to an environmental problem and abatement costs vary across the parties, a per-unit tax will produce an economically efficient outcome. The report provides several examples where per-unit taxes would be the optimal policy instrument. Among these examples are tolls to reduce urban highway congestion and carbon taxes to reduce $\mathrm{CO}_{2}$ emissions.

Tolls based on the cost that an additional car imposes on all others during congested periods would reduce congestion and allocate road capacity more efficiently. Two external costs are included in WRI's analysis: the cost of traffic delays imposed on other drivers and the cost of an increased number of accidents. Tolls reflective of congestion costs alone would range between zero and $\$ 2.10$ for an average 10 -mile trip, lead to VMT reductions of $11 \%$ on the busiest highways, and generate revenues of $\$ 44$ billion. Even when benefits are adjusted to account for the added costs to drivers of altering their travel behavior (carpools, mass transit, flex-time), the toll still results in a net welfare gain of $\$ 4$ billion. To cover both congestion and accident costs, the required toll is between zero and $\$ 3.60$ for an average 10 -mile trip. VMT is reduced by $22 \%$ and net welfare gains total $\$ 11$ billion.

The report examines the effect of imposing a tax on the producers of raw fossil fuels (primary energy) based on the relative carbon content of the fuels. Such a carbon tax would appear to consumers and manufacturers as an energy price increase. Opponents argue that carbon taxes discriminate against low-income groups, because a larger portion of their income is spent on energy. The report shows that recycling of tax revenues can significantly affect the impact of carbon taxes on overall economic health and the distribution of costs. For example, a comprehensive carbon tax program might also include an investment credit to stimulate business and a cut in payroll taxes to reduce costs to low-income groups.

Quantitative Results:

The report provides limited quantitative information: tables of scenario results without supporting data.

Peer reviewed: Not indicated 
Transportation Research Board, Committee for Study on Urban Transportation Congestion Pricing, Curbing Gridlock: Peak Period Fees to Relieve Traffic Congestion, Volumes 1 and 2, Special Report 242, 1994, 293 pages.

Mechanisms:

Reduce travel demand

Policy Instruments:

Congestion pricing

Summary:

Although congestion pricing could reduce congestion and help meet air quality goals, it remains a controversial policy option. Dismissed by transportation and government officials as infeasible in the past, the idea is being revisited because of (1) the shift in transportation policy toward demand management, (2) the worsening of congestion despite capacity expansion, (3) the inability to further expand the highway system in metropolitan areas because of clean air standards, and (4) advances in technology that have made it possible to collect fees with little motorist inconvenience.

Heightened interest in congestion pricing led the Federal Highway Administration and the Federal Transit Administration to request that the National Research Council form a study committee to (1) assess the critical issues surrounding congestion pricing, (2) recommend a potential role for congestion pricing as a demand management tool, (3) establish guidelines for evaluation, and (4) identify areas for further research. The papers commissioned by the study committee are contained in their entirety in Volume 2. Information from the papers is incorporated in Volume 1 to provide an overview of the main issues surrounding congestion pricing. Volume 1 also presents the committee's conclusions and recommendations.

The committee concluded that congestion pricing would cause (some) motorists to change their travel behavior, resulting in a net benefit to society. Although the study indicated that all income groups could benefit, assuming an appropriate distribution of revenues, some individuals would be worse off after implementation. Perceptions of fairness and public resistance to paying for services formerly viewed as free continue to pose significant political obstacles. Given that congestion pricing represents a substantial change from current policies, the committee recommended that an incremental approach be taken. Because the programs are likely to be very visible, the committee also recommended careful evaluation of changes in traffic flow, distribution of costs and benefits, and public opinion.

Quantitative Results:

- Several of the papers found in Volume 2 contain modeling results and quantitative information. Some of this quantitative information is reproduced in Volume 1, as it pertains to the more general discussion of the issues.

Peer Reviewed: Yes. 
U.S. Department of Energy, Office of Policy, Planning, and Program Evaluation, Energy Efficiency in the U.S. Economy, Technical Report One: Energy, Emissions, and Social Consequences of Telecommuting, Report DOE/PO-0026, June 1994, 112 pages.

\author{
Mechanisms: \\ Improve fuel efficiency \\ Reduce travel demand
}

Policy Instruments:

Improve telecommunications technologies/infrastructure

\title{
Summary:
}

Telecommuting is defined as the partial or complete substitution of telecommunication services for transportation to a conventional workplace. This report expands on the 1993 U.S. Department of Transportation (DOT) study on the direct effects of telecommuting - the safety, energy, and emissions effects directly associated with trips replaced by telecommuting. The DOT study intentionally excluded such indirect effects as congestion relief and induced travel or "latent" demand, the subjects of this report.

Increased levels of telecommuting can lead to significant benefits in the form of reduced traffic delays, fuel consumption, highway capacity expansion requirements, and emissions. This analysis shows that the positive direct effects of telecommuting as documented by the DOT study (reduced fuel use and vehicle emissions because telecommuters are driving less) are lessened, but not entirely offset, by the indirect effects considered (improved traffic flow, latent demand, and increased urban sprawl).

Sixteen scenarios are constructed to assess the effects of telecommuting under a wide range of assumptions about telecommuting levels, urban structure, and emissions. Latent demand and urban sprawl tend to reduce the direct benefits of telecommuting on fuel use, VMT, and emissions, while improved traffic flow tends to supplement the direct benefits with lower fuel consumption rates and emissions.

This study indicates that nearly $50 \%$ of the potential reduction in VMT directly attributable to telecommuters will be replaced by new traffic, induced by lower levels of congestion and higher average speeds. However, reduced congestion creates indirect benefits in terms of lower average emissions and fuel consumption rates, which offset the third indirect effect of increased travel attributable to urban sprawl. Thus, for VMT, fuel use, and $\mathrm{CO}_{2}$ emissions, the combined direct and indirect effects of telecommuting are positive in all scenarios.

Quantitative Results:

Extensive information on methodology, assumptions, and results are presented for such variables as emissions, travel demand, fuel efficiency, telecommuters, travel times, etc. This study does not address societal costs or costeffectiveness issues.

Peer Reviewed: Not indicated. 
U.S. Department of Transportation and U.S. Environmental Protection Agency, Clean Air Through Transportation: Challenges in Meeting National Air Quality Standards, August 1993, 52 pages.

Mechanisms:

Reduce demand (VMT, number of trips)

Improve operating efficiency

\section{Policy Instruments}

Regulation (tailpipe emissions standards, inspections)

Economic incentives (subsidies/taxes)

Nonmonetary incentives (HOV)

Summary:

The 1990 Clean Air Act (CAA) requires that the DOT and the EPA submit reports to Congress that evaluate state and local air-quality-related transportation programs. This report, the first in the series, describes the status of implementing the new transportation provisions of the CAA and the air-quality provisions of the Intermodal Surface Transportation Efficiency Act (ISTEA), and it identifies the challenges in meeting CAA requirements through transportation programs. The report covers the two-year time period from November 1990 (promulgation of the CAA) through the end of fiscal year 1992.

Together, the CAA and the ISTEA call for fundamental changes in the transportation and air-quality planning process to meet emissions reduction goals. While it is still too early to assess the effectiveness of the new programs and requirements, several observations can be made.

Traditional TCMs that focus on alternatives to SOVs (e.g., mass transit and HOV lanes) are limited in their effectiveness ( 1 to $2 \%$ emission reduction). A comprehensive TCM strategy that includes traditional and economic/market-based TCMs (such as congestion pricing, increases in parking prices, and emissions or VMT fees) could show greater emissions reductions. Capital-intensive TCMs (such as HOV lanes, transit, or intermodal facilities) are particularly questionable from a cost-effectiveness viewpoint. Although additional data and modeling are needed to accurately estimate the emissions reductions attributable to TCMs, preliminary indications are that the impact is negligible in the absence of other SOV disincentives.

Over the past 20 years, technological improvements in automobile emission rates have led to decreasing mobile source emissions despite growing VMT. Emissions reductions are expected to continue in the near term as older, high-emitting vehicles are replaced by newer, low-emitting ones. Concern that future VMT growth could offset these technological gains has resulted in an emphasis on controlling VMT. However, to the extent that vehicle technologies and unconventional fuels (reformulated gasoline, oxygenated gasoline, etc.) reduce emissions per mile, the focus for additional emissions reductions will shift to controlling the number of trips.

Understanding the interrelationship between transportation and land use is critical for formulating long-run strategies to improve air quality. It is generally accepted that high-density development better supports mass transit while lowdensity land use leads to reliance on the automobile. Economics (lower driving costs) and land-use patterns (lowdensity suburban development) have contributed to increased travel demand and higher emissions. Significant improvements in air quality will require policies that address both causal factors.

Quantitative Results:

No quantitative results are provided, although the need for data and models was addressed.

Peer Reviewed: Not indicated. 
U.S. General Accounting Office (GAO), Options to Reduce Environmental and Other Costs of Gasoline Consumption, report GAO/RCED-92-260, September 1992, 51 pages.

Mechanisms:

Improve fuel efficiency

Mode shift (increased vehicle occupancy)

Fuel substitution

Reduce travel demand

Increase R\&D

Policy Instruments:

Economic incentives (fuel taxes, tailpipe emissions tax, alternative-fuel subsidies, fee-rebate program)

Regulation (higher CAFE standards)

Accelerated vehicle scrappage program

Summary:

This report assesses the ability of six policy options (listed above) to address the "external" costs of gasoline consumption and achieve several policy objectives, including environmental quality, energy security, and petroleum conservation. The effect of each policy option is evaluated with respect to a set of objectives. The options are not assessed in terms of cost-effectiveness, but the advantages and disadvantages of each option are discussed. The General Accounting Office analysis is based on literature review and expert interviews, not original modeling.

The assessment concludes that while all six policy options reduce air pollution caused by gasoline consumption and our dependence on petroleum, the gasoline tax and tailpipe emissions tax meet more of the objectives than the other options. Negative trade-offs of these two options could be slower economic growth and a greater financial burden on low-income groups. The report emphasizes that policy options may be combined and/or modified to eliminate some of the negative trade-offs. For example, tax revenues can be "recycled" to reduce the effects on economic growth and the disproportionate burden on low-income groups.

Quantitative Results:

The report is entirely descriptive; no quantitative analysis is conducted.

Peer Reviewed:

Staff from the EPA and the DOE reviewed the report and were in general agreement with the information presented. 


\section{Documents and Related Reference Materials}

Annual Symposium Series on the Transportation, Land Use, Air Quality Connection, Summary of Proceedings, The Role of Land Use Strategies for Improving Transportation and Air Quality, Public Policy Program, UCLA Extension, Los Angeles, Calif., Nov. 1993.

Annual Symposium Series on the Transportation, Land Use, Air Quality Connection, Summary of Proceedings, Overview of Strategies for Making Connections Between Transportation, Land Use and Air Quality, Public Policy Program, UCLA Extension, Los Angeles, Calif., Nov. 1993.

Apogee Research, Evaluation of the $\mathrm{CO}_{2}$ Implications of the Intermodal Surface Transportation Efficiency Act of 1991, prepared for U.S. Environmental Protection Agency, Office of Policy Analysis, 1992.

Automobile Club of Southern California, Field Evaluation of Miles-Per-Gallon Meters, DOT-TSC-OST-77-64, prepared for U.S. Department of Transportation, Nov. 1997.

Bartholomew, K., "Making the Land Use, Transportation, Air Quality Connection (LUTRAQ)," Transportation, in press.

Brinner, R., et al., An Analysis of Public Policy Measures to Reduce Carbon Dioxide Emissions from the U.S. Transportation Sector, DRI/McGraw-Hill for U.S. Environmental Protection Agency, Lexington, Mass., Jan. 1991.

Brinner, R., M. Shelby, J. Yanchar, and A. Cristofaro, Optimizing Tax Strategies to Reduce Greenhouse Gases Without Curtailing Growth, DRI/McGraw-Hill for U.S. Environmental Protection Agency, Lexington, Mass., Jan. 1991.

Cameron, M., Transportation Efficiency: Tackling Southern California's Air Pollution and Congestion, Environmental Defense Fund and Regional Institute of Southern California, Oakland, Calif., March 1991.

Cameron, M., Efficiency and Fairness on the Road, Strategies for Unsnarling Traffic in Southern California, Environmental Defense Fund, Oakland, Calif., 1994.

Cheslow, M., Fuel Savings from IVHS Deployment: Initial Estimates for 2000 and 2010, IVHS America Annual Meeting, Newport Beach, Calif., May 1992.

Davis, S.C., Transportation Energy Data Book: Edition 14, ORNL-6798, Oak Ridge National Laboratory, May 1994. 
Deakin, E., "Urban Transportation Congestion Pricing Effects on Urban Form," in Curbing Gridlock: Peak Period Fees to Relieve Traffic Congestion, Volume 2, Committee for Study on Urban Transportation Congestion Pricing, Transportation Research Board, Special Report 242, National Academy Press, Washington, D.C., 1994.

DeCicco, J., and D. Gordon, Steering with Prices: Fuel and Vehicle Taxation as Market Incentives for Higher Fuel Economy, American Council for an Energy-Efficient Economy, Washington, D.C., Dec. 1993.

DeCicco, J., and M. Ross, An Updated Assessment of the Near-Term Potential for Improving Automotive Fuel Economy, American Council for an Energy-Efficient Economy, Washington, D.C. Nov. 1993.

DeCicco, J., H. Geller, and J. Morril, Feebates for Fuel Economy, American Council for an Energy Efficient Economy, Washington, D.C., May 1993.

DeCicco, J.M., A Critique of the National Research Council Study of the Potential for Improving Automotive Fuel Economy, SAE Government/Industry Meeting \& Exposition, Washington, D.C., April, revised Sept 1, 1992.

DeCicco, J.M., Savings from CAFE Projections of the Future Oil Savings from Light Vehicle Fuel Economy Standards, American Council for an Energy-Efficient Economy, Washington, D.C., May 1992.

DeCicco, J.M., et al., "Transportation on a Greenhouse Planet: A Least-Cost Transition Scenario for the United States," in Transportation and Global Climate Change, American Council for an Energy Efficient Economy, Washington, D.C., 1993.

DeLuchi, M.A., Emissions of Greenhouse Gases from the Use of Transportation Fuels and Electricity, Vol. 1: Main Text, ANL/ESD/TM-22, Argonne National Laboratory, Nov. 1991.

Energy and Environmental Analysis, Inc., Automobile Fuel Economy Potential to 2005, prepared for U.S. Department of Energy, Office of Policy, Planning, and Program Evaluation, draft, April 1994.

Energy and Environmental Analysis, Inc., Domestic Manufacturers' Light Duty Truck Fuel Economy Potential to 2005: Final Report, prepared for U.S. Department of Energy, Office of Policy, Planning, and Program Evaluation, Jan. 1994.

Energy and Environmental Analysis, Inc., Fuel Economy Technology and Cost Documentation: Final Report, prepared for U.S. Department of Energy, Office of Policy, Policy, Planning, and Program Evaluation, April 1994. 
Energy Information Administration, Household Vehicles Energy Consumption 1991, DOE/EIA-0464, U.S. Department of Energy, 1991.

Energy Information Administration, Annual Energy Outlook, 1994, DOE/EIA-0383(94), U.S. Department of Energy, Jan. 1994.

Energy Information Administration, Annual Energy Review 1993, DOE/EIA-0384(93), U.S. Department of Energy, July 1994.

European Council of Ministers of Transport, OLIS, Urban Travel and Sustainable Development: Report of the Joint OECD/ECMT Group, CEMT/CM(94)17, Paris, France, April 1994.

Federal Highway Administration, Our Nation's Highways: Selected Facts and Figures, FHWA-PL-90-024, U.S. Department of Transportation, Oct. 1990.

Federal Highway Administration, 1990 Nationwide Personal Transportation Survey - Summary of Travel Trends, FHWA-PL-92-027, U.S. Department of Transportation, March 1992.

Federal Highway Administration, 1990 Nationwide Personal Transportation Survey - Databook, Vol. I, FHWA-PL-94-010A, U.S. Department of Transportation, Nov. 1993.

Federal Highway Administration, 1990 Nationwide Personal Transportation Survey - Databook, Vol. II, FHWA-PL-94-010B, U.S. Department of Transportation, Nov. 1993.

Federal Highway Administration, National Bicycling and Walking Study, Case Study No. 9: Linking Bicycle/Pedestrian Facilities with Transit, U.S. G.P.O.: 1993-343-273:80213, U.S. Department of Transportation, 1993.

Federal Highway Administration, 1990 Nationwide Personal Transportation Survey - Urban Travel Patterns, FHWA-PL-94-018, U.S. Department of Transportation, June 1994.

Federal Highway Administration, 1993 Highway Statistics, FHWA-PL-94-023, U.S. Department of Transportation, Oct. 1994.

Gordon, D., Steering a New Course: Transportation, Energy and the Environment, Union of Concerned Scientists, Cambridge, Mass., 1991.

Greene, D.L., Short Term Options for Controlling $\mathrm{CO}_{2}$ Emissions of Light Duty Vehicles, Society of Automotive Engineers (SAE) Technical Paper 901111, SAE Government/Industry Meeting \& Exposition, Washington, D.C., May 1990. 
Greene, D.L., "Vehicle Use and Fuel Economy: How Big Is the 'Rebound' Effect," The Energy Journal, 13(1):117-143, 1992

Greene, D.L., and Y. Fan, Transportation Energy Efficiency Trends, 1972-1992, ORNL-6828, Oak Ridge National Laboratory, Dec. 1994.

Gushee, D.E., Potential Policy Levers for Alternative Fuels: Costs, Energy Security, and Environmental Impacts, Congressional Research Service, Washington, D.C., April 27, 1992.

Hadder, G.R., S. Webb, and M. Clauson, The Potential for Low Petroleum Gasoline, Draft 2 (March 27, 1995), prepared by Oak Ridge National Laboratory and Energy and Environmental Analysis, Inc., 1995.

Haltmaier, S., The Replacement of Transportation Subsidies with Optimal Highway Pricing and Investment, DRI/McGraw-Hill for U.S. Environmental Protection Agency, Lexington, Mass., May 1994.。

Harvey, G., "Transportation Pricing and Travel Behavior," in Curbing Gridlock: Peak Period Fees to Relieve Traffic Congestion, Volume 2, Committee for Study on Urban Transportation Congestion Pricing, Transportation Research Board, Special Report 242, National Academy Press, Washington, D.C., 1994.

J.D. Power and Associates, Impact of Fuel Economy Information on New Car and Light Truck Buyers, prepared for U.S. Department of Energy, May 1981.

Johnson, E., Avoiding the Collision of Cities and Cars: Urban Transportation Policy for the Twenty-First Century, American Academy of Arts and Sciences, Chicago, Ill., 1993.

Jones, C., "Another Look at U.S. Passenger Vehicle Use and the 'Rebound' Effect from Improved Fuel Efficiency," The Energy Journal, 14(4):99-110, 1993.

Kessler, J., and W. Schroeer, "Meeting Mobility and Air Quality Goals," Transportation, in press.

Krupnick, A.J., M.A. Walls, and C.T. Collins, Global Warming and Urban Smog: The CostEffectiveness of CAFE Standards and Alternative Fuels," The Energy Journal 14(4):75-97, 1993.

Laitner, S., Energy Savings and Job Impacts from the Proposed Energy Tax, American Council for an Energy-Efficient Economy, Washington, D.C., July 1993. 
Lawrence Berkeley Laboratory, Effects of Feebates on Vehicle Fuel Economy, Carbon Dioxide Emissions and Consumer Surplus, prepared for U.S. Department of Energy, draft, Nov. 1994.

Loudon, W. R., D.A. Dagang, and R.G. Dulla, The Effectiveness of Transportation Control Measures in Reducing Congestion and Improving Air Quality, Air \& Waste Management Association, 86th Annual Meeting \& Exhibition, June 1993.

MacKenzie, J.J., The Keys to the Car: Electric and Hydrogen Vehicles for the 21st Century, World Resources Institute, May 1994.

Magid, L., Breaking Out of the Automobile Regulation Box: Achieving Automobile Policy Goals through Cooperation between U.S. Auto Manufacturers, Environmental and Consumer Groups, Kennedy School of Government, Harvard University, April 1994.

Mark, J., J.M. Ohi, and D.V. Hudson, Fuel Savings and Emissions Reductions from Light Duty Fuel Cell Vehicles, NREL/TP-463-6157, National Renewable Energy Laboratory, April 1994.

Mason, J.J., and J. DeCicco, "IC Engines and Fuels for Cars and Light Trucks: 2015," in Transportation and Global Climate Change, American Council for an Energy Efficient Economy, Washington, D.C., 1993.

Miles-McLean, R., S.M. Haltmaier, and M.G. Shelby, "Designing Incentive-Based Approaches to Limit Carbon Dioxide Emissions from the Light-Duty Vehicle Fleet," in Transportation and Global Climate Change, American Council for an Energy-Efficient Economy, Washington, D.C., 1993.

Murrell, J.D., K. Hellman, and R.M. Heavenrich, Light-Duty Automotive Technology and Fuel Economy Trends Through 1993, EPA/AA/TDG/93-01, U.S. Environmental Protection Agency, Office of Mobile Sources, May 1993.

Nadis, S., and J. MacKenzie, Car Trouble, Beacon Press, 1993.

National Research Council, Automotive Fuel Economy, How Far Should We Go?, National Academy Press, Washington, D.C., 1992.

Nordhaus, W.D., "An Optimal Transition Path for Controlling Greenhouse Gases," Science, 258:20,1315-1319, 1992.

Office of Technology Assessment, U.S. Congress, Changing by Degrees, Steps to Reduce Greenhouse Gases, Washington, D.C., Feb. 1991. 
Office of Technology Assessment, U.S. Congress, Saving Energy in U.S. Transportation, OTA-ETI-589, July 1994.

Office of Technology Assessment, U.S. Congress, Improving Automobile Fuel Economy, New Standards, New Approaches, Washington, D.C., undated.

Office of the Vice President, Climate Change Action Plan, Oct. 1993.

Organization for Economic Co-Operation and Development, Climate Change Policy Initiatives, Paris, France, 1992.

Organization for Economic Co-Operation and Development, Climate Change, Designing a Practical Tax System, Paris, France, 1992.

Organization for Economic Co-Operation and Development, Climate Change, Designing a Tradeable Permit System, Paris, France, 1992.

Organization for Economic Co-Operation and Development, Cars and Climate Change, Paris, France, 1993.

Orkand Corporation, Followup Study to the DECAT Program, Sept. 1982.

Pisarski, A., 1990 Nationwide Personal Transportation Survey - Travel Behavior Issues in the 90's, FHWA-PL-93-012, Federal Highway Administration, U.S. Department of Transportation, July 1992.

Public Policy Program, UCLA Extension, The Role of Land Use Strategies for Improving Transportation and Air Quality, Summary of Proceedings, Annual Symposium Series on the Transportation, Land Use, Air Quality Connection, Los Angeles, Calif., November 7-9, 1993.

Public Policy Program, UCLA Extension, Overview of Strategies for Making Connections Between Transportation, Land Use, and Air Quality, Summary of Proceedings, Annual Symposium Series on the Transportation, Land Use, Air Quality Connection, Los Angeles, Calif., November 6-8, 1991.

Repetto, R., R. Dower, R. Jenkins, and J. Geoghegan, Green Fees: How a Tax Shift Can Work for the Environment and the Economy, World Resources Institute, Nov. 1992.

Ross, M., M. Ledbetter, and F. An, Options for Reducing Oil Use by Light Vehicles: An Analysis of Technologies and Policy, American Council for an Energy-Efficient Economy, Washington, D.C., Dec. 1991. 
Schroeer, W., A Cost-Effective Accelerated Scrappage Program, Annual Meeting of the Transportation Research Board, Washington, D.C., Jan. 1992.

Sperling, D., Future Drive: Electric Vehicles and Sustainable Transportation, Island Press, Washington, D.C., Jan. 1995.

Transportation Research Board, Curbing Gridlock, Peak-Period Fees to Relieve Traffic Congestion, Vols. I and II, Special Report 242, 1994.

U.S. Department of Energy, Advanced Vehicle Technologies Plan, preliminary draft, Feb. 1994.

U.S. Department of Energy, Office of Environmental Analysis, Limiting Net Greenhouse Gas Emissions in the United States, Vols. I and II, DOE/PE-0101, R.A. Bradley, E.C. Watts, and E.R. Williams (editors), Sept. 1991.

U.S. Department of Energy, Office of Policy, Planning and Program Evaluation, Energy Efficiency in the U.S. Economy, Technical Report One: Energy, Emissions, and Social Consequences of Telecommuting, DOE/PO-0026, June 1994.

U.S. Department of Energy, Office of Transportation Programs, Five Year Transportation Program Plan, draft, Aug. 1994.

U.S. Department of Transportation and U.S. Environmental Protection Agency, Clean Air Through Transportation: Challenges in Meeting National Air Quality Standards, Aug. 1993.

U.S. Department of Transportation, The Effectiveness of Miles-Per-Gallon Meters as a Means to Conserve Gasoline in Automobiles, DOT-TSC-OST-76-38, Oct. 1976.

U.S. Department of Transportation, National Urban Mass Transportation Statistics, Annual Report of the Federal Transit Administration, 1979-1991.

U.S. Department of Transportation, Bureau of Transportation Statistics, National Transportation Statistics: 1993 Annual Report, DOT-VNTSC-BTS-93-1, Sept. 1993.

U.S. Department of Transportation, Bureau of Transportation Statistics, Transportation Statistics: 1993 Annual Report, DOT-VNTSC-BTS-93-1, Jan. 1993.

U.S. Department of Transportation, Bureau of Transportation Statistics, Trans-Border Surface Freight Transportation Data, BTS-FD-06-01, Aug. 1994. 
44

U.S. Environmental Protection Agency, Bicycling and Air Quality Information Document, EPA-400/2-79-001, 1979.

U.S. Environmental Protection Agency, Preliminary Technology Cost Estimates of Measures Available to Reduce U.S. Greenhouse Gas Emissions by 2010, Aug. 1990.

U.S. General Accounting Office, Options to Reduce Environmental and Other Costs of Gasoline Consumption, GAO/RCED-92-269, Sept. 1992.

World Wildlife Fund and The Conservation Foundation, Carbon Emissions Control Strategies: Case Studies in International Cooperation, W.U. Chandler (editor), Washington, D.C., undated. 